\title{
THE RELATIONSHIP BETWEEN ALQURAN AND LANGUAGE
}

\author{
By
}

\author{
Yusni Sinaga, M.Hum ${ }^{1}$
}

\begin{abstract}
Abstrak
Alquran merupakan buku petunjuk penggunaan dan perawatan semua benda yang ada di duniaini. Benda yang dimaksud adalah benda hidup maupun benda mati. Seperti manusia, tumbuhan, jin, hewan dan benda-benda lainnya yang bertempat di bumi, langit dan yang ada diantara keduanya. Buku petunjuk ini ditunjukkan bagi manusia sebagai khalifah yang Allah Swt pilihkan untuk memimpin di muka bumi, jadi Alquran hanya diberikan kepada makhluk lain seperti malaikat, jin, hewan, dan tumbuhan. Manusia adalah makhluk yang paling istimewa yang salah satu keistemewaan manusia adalah kemampuan menggunakan manusia.

Bahasa adalah salah satu alat manusia untuk berkomunikasi dengan penciptanya dan dengan makhluk sesamanya seperti Alquran dalam bahasa arab adalah alat manusia berkomunikasi dengan Allah Swt. Untuk bias memahami perintah dan larangan dari Allah Swt sebagai pencipta bumi, langit, dan yang ada diantara keduanya sehingga semua benda yang digunakan manusia selama dalam kehidupannya diri dhoi oleh pemiliknya yaitu Allah Swt. Ala tkomunikasi yang dimaksudkan adalah bahasa yang meliputi empat kemampuan berbahasa yaitu mendengarkan, berbicara, membaca dan menulis. Bahkan penjelasan tentang keempat kemampuan berbahasa inipun bias ditemukan dalam Alquran.
\end{abstract}

Key word : Allah Swt, Alquran, BahasadanMakhluk

\section{A. INTRODUCTION}

\section{Listening}

Listening is the first skill gotten by human soon after seoulblewn by allahSwt, and this is the most excellent skill among of the all language skill because listening has been gotten since the infant still it's mom's tummy or before borntwhere as the other language skills are such as speaking, reading, and writing will be beengotten after be bornt. The listening skill can be owned gotten before baby is able to speak, to read, it can be seen on syuroh as-sajadah (32:9).

\section{O的 $\rightarrow$ 的

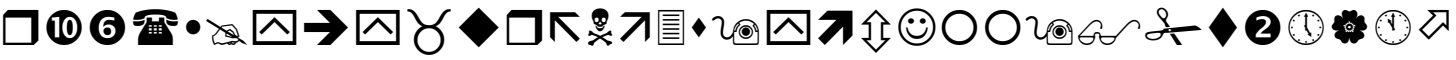

\footnotetext{
${ }^{1}$ Writer is an English Department Lecturer of Tarbiyah and Teacher Training Faculty (FTIK), Institute for Islamic Studies (IAIN) Padangsidimpuan.
} 
32:9 Then He fashioned him and breathed into him of His Spirit; and appointed for you hearing and sight and hearts. Small thanks give ye! ${ }^{2}$

(Kemudian Dia menyempurnakan dan meniupkan kedalam nyaroh (ciptaan)Nyadan Dia menjadikan bagi kamu pendengaran, penglihatan dan hati; (tetapi) kamu sedikit sekali bersyukur). ${ }^{3}$

After Getting the listening skill then the comprehending on feeling comes, by having feeling the infant can give responds or reactions to it's environment in it's mom's tummy.

Before the comprehending comes an infant can not give respond to what is happened in this environment, means the infant still as a unloving thing as shown in Alqur-an As Sajadah verse 9 above and Alqur'ansyuroh Al-mulk (67: 23).

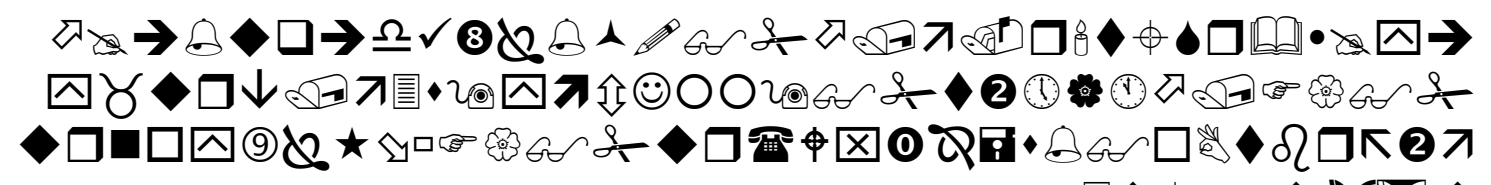

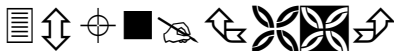

67:23 Say (unto them, O Muhammad): He it is who gave you being, and hath assigned unto you ears and eyes and hearts. Small thanks give ye! ${ }^{4}$

(Katakanlah: "Dia-lah Yang menciptakan kamu dan menjadikan bagi kamu pendengaran, penglihatan dan hati." (Tetapi) amat sedikit kamu bersyukur). ${ }^{5}$

By looking at the end of the both syuroh show us that after getting listening human ask to thank or to prise to Allah SWT. Thank to Allah SWT is one of the giving respond to what has been given.

Listening is the one of receptive skills beside reading but the listening skill comes first before reading because reading is gotten after getting the speaking ability where as the speaking ability gotten after the infant born or used to be called as a baby.

\footnotetext{
${ }^{2}$ http://ayatalquran.net/2015/01/surah-as-sajdah-the-prostration-terjemah-bahasa-inggris, diakses, Rabu, 18 Juli 2018, pkl 11.00.

${ }^{3}$ ArifFakhrudin\&SitiIrhamah, Al Hidayah Al-Qur'an Tafsir Per Kata TajwidKodeAnga, (Tangerang Selatan: KalimKaryaIlmu,Karya Hayati.2011), p.532.

${ }^{4}$ http://ayatalquran.net/2015/01/surah-al-mulk-the-prostration-terjemah-bahasa-inggris, diakses, Rabu, 18 Juli 2018, pkl 11.10.

${ }^{5}$ ArifFakhrudin\&SitiIrhamah, Op. Cit.,hlm. 563.
} 
The listening skill is the most important among of those all language skills because without the listening skill human is cannot able to speak not to read.

Base on some verses in Alquran by using the listening skill well to what is said by Allah swt in his Quran and his Rasulullah story reward be gotten from Allah means the happiness in the world and in the here after later on. So, listening is the natural precursor to speaking. ${ }^{6}$

\section{Speaking}

Speaking is a process of production or delivering feeling and desire by utterances or body language. After be bornt a baby soon to cry, the crying means that the baby wants to deliver or wants to say something. So, the crying is the very basic way to speak gotten by people. Soon after be bornt longer and longer will develop as the baby's development of its body. Speaking also is to produce a higher standard of spoken language in terms of accuracy, precision, coherence and appropriatenes. ${ }^{7}$

\section{B. THEORETICAL DESCRIPTION}

\section{Defenition of Speech}

Some scholars argue that speaking is the ability to pronounce articlation or words to express, express and convey thoughts, ideas and feelings. More broadly speaking it is a form of human action that exploits physical, psychological, neurological, semantic and linguistic factors extensively and extensively so that it can be regarded as the most important human tool in social control. Thus it can be said that in the activity of talking occurs the process of conception of mind and feelings into a form of speech or sound language meaningful. Speaking is not just a meaningless saying, but conveying thoughts or feelings to others through speech or by spoken language.

Speaking is also an activity anyone can do even if a newborn person speaks crying, which is the first time the master is to learn something about talking. They often talk so they can say what they say by car repetitively.

As for some commands berbicaa in al-Qur'an that is:

6 I.S.P. Nation Jonathan Newton, Teaching ESL/EFL Listening and Speaking,(Francis: Routledge,2009),p.37.

${ }^{7}$ Ibid, p. 116. 


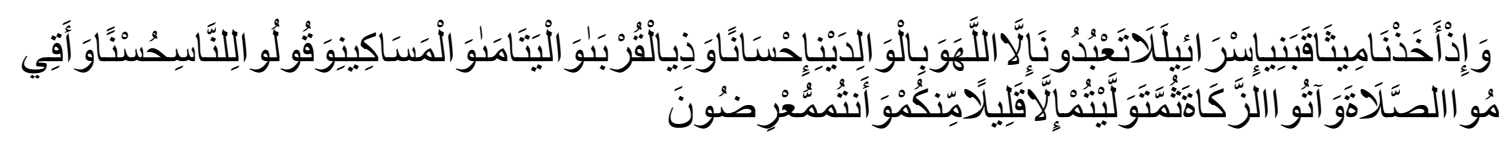

2:83 And (remember) when We made a covenant with the Children of Israel, (saying): Worship none save Allah (only), and be good to parents and to kindred and to orphans and the needy, and speak kindly to mankind; and establish worship and pay the poor-due. Then, after that, ye slid back, save a few of you, being averse. ${ }^{8}$

("Dan berbicaralah kepada orang-orang dengan baik...") (Q.S.Al-
Baqarah:83)

In the book of commentary jalalain explained that a good greeting of which is an honest greeting, gentle, and which contains the invitation to do good and avoid evil. This verse is a series of discussions about the Children of Israel who have vowed not to worship but Allah. And do good to parents, relatives, orphans, and poor people. The verse - 83 of this sura al-Baqarah also commands them to establish prayers and perform zakat. Wallohu 'a'lam.

As in another verse in Surah al-Baqarah (verse: 44), namely:

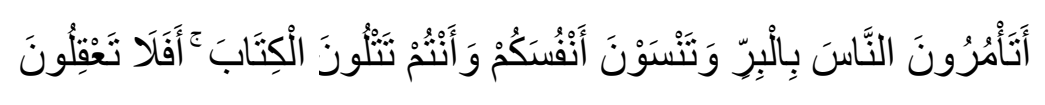

2:44 Enjoin ye righteousness upon mankind while ye yourselves forget (to practise it)? And ye are readers of the Scripture! Have ye then no sense? ${ }^{10}$

("mengapa kamu suruh orang lain (mengerjakan kebaikan), sedang kamu melupakan diri (kewajiban) ти sebdiri, padahal kamu membaca al-Kitab (Taurat). Maka, tidakkah kamu berpikir? $)^{11}$

Although the above verses are only shown to the Children of Israel directly, but their content is also shown to Muslims by signaling that humans should not order good people. Whereas herself will not do it.

Where, the intent of these two verses is that someone is saying to do something good that he himself does not do at all.

\footnotetext{
${ }^{8}$ http://ayatalquran.net/2015/01/surah-al-baqarah--the-cow-terjemah-bahasa-inggris, diaksesRabu, 18 juli 2018, pukul 20.32 .

${ }^{9}$ ArifFakhrudin\&SitiIrhamah, Op. Cit.,hlm. 13.

${ }^{10}$ http://ayatalquran.net/2015/01/surah-al-baqarah-the-cow-terjemah-bahasa-inggris, diaksesRabu 18 Juli 2018, pukul 20.49.

${ }^{11}$ ArifFakhrudin\&SitiIrhamah, Op. Cit.,hlm. .8.
} 
If a person contradicts the actions of his words contained in the two letters, then the one who says something must make it happen in his deeds. Speech should not conflict with deeds

Should a person live with his belief. And everything must be adjusted to the beliefs that are in his heart, both his picranyya and his feelings. Then with his deeds. Anyone who has never performed the night prayer, then let him not advise others to perform the prayer lail (night). Otherwise, he should be ashamed of himself. Anyone who can not perform prayers solemnly and calmly. Do not advise others to perform 'special prayers' and be calm. God's relationship is strongly influenced by the utterance of one who utters, but he does not want to realize it by his actions. Think carefully about the person who speaks to defend Islam, but they can not make it happen in their deeds. In fact many of their actions are contrary to their speech

The other verses that talk about speaking are:

2:118 And those who have no knowledge say: Why doth not Allah speak unto us, or some sign come unto us? Even thus, as they now speak, spake those (who were) before them. Their hearts are all alike. We have made clear the revelations for people who are sure. ${ }^{12}$

("Dan orang-orang yang tidak mengetahui berkata: "Mengapa Allah tidak (langsung) berbicara kepada kami atau datang tanda-tanda kekuasaanya kepada kami" Demikian pula orang-orang yang sebelum mereka telah mengatakan seperti ucapan mereka itu; hati mereka serupa.Sesungguhnya kami telah menjelaskan tanda-tanda kekuasaan kami kepada kaum yang menggetahui $)^{13}$

(And those who do not know) ie the kafir mecca to the Prophet. ("Why did God not speak with us) that you are his Apostle (or come to us a sign) or evidence we show to show your truth". (thus also) means as they say it. (Told to the people before them) ie the ummah who disbelieved against their prophet.

Each (as they say) in the form of insubordination and the request of miracles. (Their hearts are alike) ie in disbelief and dissent. This became a holiday and persuasion for the Prophet. (In fact we have explained our power to you that are certain.) Who knows that he is a verse sign so that traders believe, so suggesting other signs is a sin or a mistake.

\footnotetext{
${ }^{12}$ http://ayatalquran.net/2015/01/surah-al-baqarah-the-cow-terjemah-bahasa-inggris, diaksesRabu 18 Juli 2018, pkl. 21.00.

${ }^{13}$ ArifFakhrudin\&SitiIrhamah, Op. Cit.,hlm. 19.
} 


\section{Reading and Qur'an}

Speaking and writing are language producted skills where as listening and reading are language reciepted skills. Listening is the first language receipted and reading is the last language receipted.

Reading is a process of taking information of decoding symbol in letters forming in order to derive meaning. Through reading people can add knowledge, improving understanding, prepation to action, tools of communication, getting imagination and creativity and reading is an active process that requires a great deal of practice and skill. ${ }^{14}$ Then according to Caroline, Reading is a set of skills that involves making sense and deriving meaning from a printed word. ${ }^{15}$

Reading is one activity that has a myriad of benefits. Where in the Qur'an "the command of reading is in the first revelation, although it is addressed through Prophet Muhammad SAW, who is not good at reading".

The Qur'an as well as the holy book of Islam is also the main source in every discipline of science, answering every problem or problem faced by thinkers, whether from Islamic thinkers or Western thinkers, how not?

That's because the command of reading contained in the Qur'an that contains the concept of aspects of life including in it is the science so that revelation becomes the only source and principle for the activity of reading and writing itself.

Where the recitation of the Qur'an is one of the worship for Muslims that should first be done, before the other religious charity, the command that was first revealed by Allah SWT to Prophet Muhammad SAW is the command to recite the Qur'an. And it is the revelation that was first revealed through the intercession of the angel Gabriel.

Reading the Qur'an includes a noble deed, and Allah promises a double reward for those who do so. Although we do not understand meaning or meaning.

A believer who does not read the Qur'an means he has omitted one of his essential qualities that is good in his Zahir. This is a deficiency for a Muslim person who should be able to read the Qur'an, memorize it and to tadabbur.

\footnotetext{
14 Judi Moreillon, Collaborative strategies for teaching reading comprehension, (Chicago: American Library Association, 2007), p. 10.

15 Caroline, T. Linse, Practical English Language Teaching: Young Learners, (New York: McGraw-Hill, 2005), p. 69.
} 
Where described in the letter of Al-Baqarah verse 121 below:

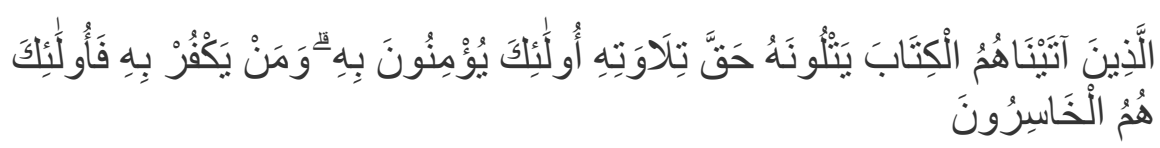

Which means: "those whom we have given the Book to them, they read it with true reading, they believe in it. And whosoever rebelled against them, they shall be the losers.

(Orang-orang yang telah Kami berikan Al Kitab kepadanya, mereka membacanya dengan bacaan yang sebenarnya, mereka itu beriman kepadanya.Dan barangsiapa yang ingkar kepadanya, maka mereka itulah orang-orang yang rugi). ${ }^{17}$

From Abu Musa Al Asy'ari R.A said, Rasulullah SAW said:

"The parable of the believers who read the Qur'an is like a lemon; it smells and tastes good and the likes of the believers who do not read the Qur'an are like the date palms; no smell but good taste. And the parable of the hypocrites who read the Qur'an is like a raihanah fruit, fragrant smell but bitter taste, and the hypocrites who do not read the Qur'an is like a fruit Hanzalah no smell and bitter taste ". (Narrated by Bukhari and Muslim).

Attempts to know the content and purpose of the Qur'an have resulted in translation and interpretation in various languages. However, the result of the effort is limited to human effort to find the hidden meaning of mean in the Qur'an.

The Qur'an which is revealed to the Prophet Muhammad with a clear explanation there is no doubt in it and no one can change the content of the Qur'an.

The Qur'an is also conveyed to Muslims who are worthy of worship in it for those who want to read it.

Benefits of reading the Qur'an

1. Gaining worship and reward

2. Gain a higher degree

3. Providing knowledge, peace and quiet, etc.

Below is a verse that suggests reading in Alquran

QS. Al-Baqarah verse 129

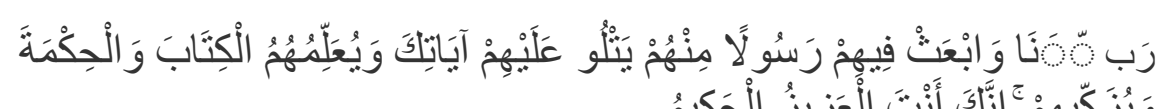

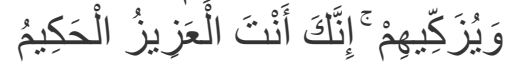

\footnotetext{
${ }^{16}$ http://ayatalquran.net/2015/01/surah-al-baqarah-the-cow-terjemah-bahasa-inggris, diaksesRabu 18 Juli 2018, pkl. 21.15.

${ }^{17}$ ArifFakhrudin\&SitiIrhamah, Op. Cit.,hlm. 20.
} 
Meaning: "Our Lord, send for them an apostle from among them who will recite to them your Signs and teach them the Books and Al-Hikma (Sunnah) and purify them. You are the Almighty, the Wise. "18

(Ya Tuhan kami, utuslah untuk mereka seorang Rasul dari kalangan mereka, yang akan membacakan kepada mereka ayat-ayat Engkau, dan mengajarkan kepada mereka Al Kitab (Al Qur'an) dan Al-Hikmah (As-Sunah) serta menyucikan mereka. Sesungguhnya Engkaulah yang Maha Perkasa lagi Maha Bijaksana). ${ }^{19}$

QS. Al-Baqarah verse 151

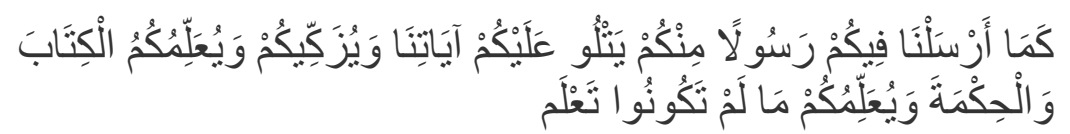
Meaning: "As (we have perfected our favor to you) we have sent you an Apostle among you who recite our verses to you and sanctify them and teach you the Book and teach you what you do not know. "20

(Sebagaimana (Kami telah menyempurnakan nikmat Kami kepadamu) Kami telah mengutus kepadamu Rasul di antara kamu yang membacakan ayat-ayat Kami kepada kamu da nmenyucikan kamu dan mengajarkan kepadamu Al Kitabdan Al-Hikmah (As Sunah), serta mengajarkan kepada kamu apa yang belum kamu ketahui). ${ }^{21}$

Where in reading the Qur'an is very important for us to determine the makhrajul letters (places of letter out).

The division of places of exit letters / Makhrajul letters Hijaiyah there are 5 places are:

1. Al-Jauf (oral or oral cavity)

Oral cavity and laryngeal throat is where the letters hijaiyah lies in the oral cavity and throat cavity.

The sounds of letters coming out of the oral cavity or throat cavity there are three kinds:

a. Alif and earlier there are letters that in the fattah

b. Waw died and before that there was a letter in the dommah

c. Yes' dead and previous letters are on kasrah

2. Al-Halqu (throat / throat)

Throat or esophagus is the place of the sound of letters hijaiyah located on the throat / throat and based on technical differences pronunciation. The letters hijaiyah out of the throat is divided into three parts, namely:

a. AqshalHalqy (larynx), the letters of hamzah and yes

b. WashlulHalqy (mid-throat), the letters Ha and 'Ain

\footnotetext{
${ }^{18}$ http://ayatalquran.net/2015/01/surah-al-baqarah-the-cow-terjemah-bahasa-inggris, diaksesRabu 18 Juli 2018, pkl. 21.30.

${ }^{19}$ ArifFakhrudin\&SitiIrhamah, Op. Cit.,hlm. 21.

${ }^{20} \mathrm{http}$ ://ayatalquran.net/2015/01/surah-al-baqarah-the-cow-terjemah-bahasa-inggris, diaksesRabu 18 Juli 2018, pkl. 21.40.

${ }^{21}$ ArifFakhrudin\&SitiIrhamah, Op. Cit.,hlm. 24.
} 
c. AdnalHalqy (throat end), the letters Ghain and Kho

3. Al- Lisnu (tongue) / asy-syafatain (two lips)

The tongue of the letter hijaiyah with the exit from the lida there are 18 letters, based on the 18 letters it can be grouped into 10 makhraj, as follows:

a. The base of the tongue and touch the sky of the back of the mouth, the letters Qaf

b. The base of the middle tongue and the middle of the mouth of the mouth of the letter kaf

c. Middle of the tongue of the letters Jim, syin, and yes', (out of the middle labgitsky)

d. The base of the tongue, dhad letters

e. The edge of the tongue, the lam. (touching the front sky in the mouth)

\section{DISCUSSION}

\section{Writing And Alquran}

As speaking is an utterances used to delivery feeling and desire by producing sound by mouth or body so writing is produced in grapic signs and can be said that writing is writing is an activity of pouring the thoughts, ideas and feelings of a person expressed in written language.Axelrod and Coopers state that writing is a complex process ans as such contains element of mystery and surprise. ${ }^{22}$ According to Penny, writing normally uses a generally acceptable standard variety of the language. ${ }^{23} \mathrm{~A}$ written text conforms more to conventional rules of grammar, and its vocabulary is more precise. It means, the language is solid, explicit, logic, and interesting. So, writing has the language that comprehended by reader.According to Fachruddin in Endang, "menulismerupakankemampuanmengungkapkanpikirandanjugaperasaandalamtulisan yang efektif. ${ }^{24}$ (Writing is the ability to express the thinking and feeling on effective written).

The word of writing is contained in the letter of Al-Baqarah verse 282

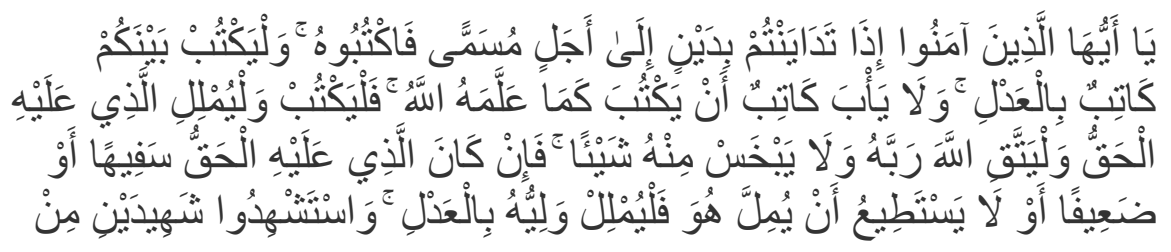

22 Rise B. Axelrod and Charles R. Coopers, the St. Martin's Guide to Writing (New York: St Martin's Press, Inc, 1985),p.3.

${ }^{23}$ Penny Ur, A Course in Language Teaching, (Ne York: Cambridge University Press, 1991),p.61.

${ }^{24}$ EndangKasupardi and Supriatna, PengembanganKeterampilanMenulis, (Jakarta: Trans MandiriAbadi, 2010),p.5 


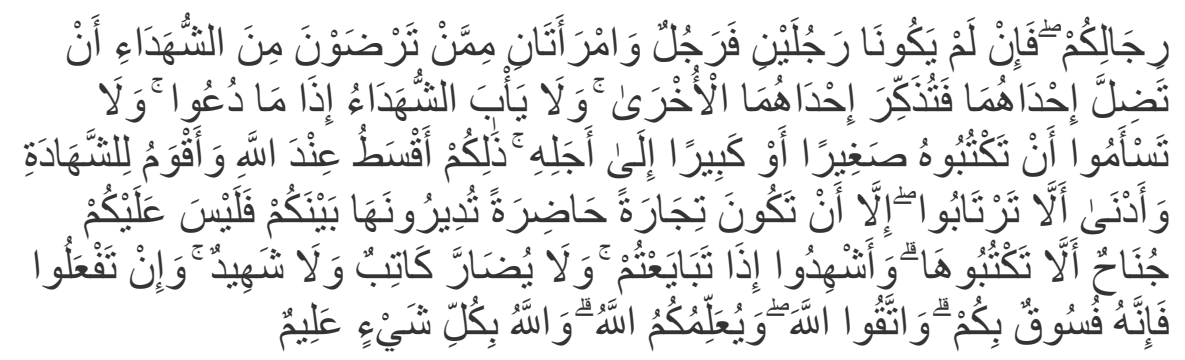

Meaning: You are a believer, if you do not trust in cash for a prescribed time, you should write. And let a writer among you write it correctly. And let the writer not reluctant to write it as Allah taught it, so let him write, and let the debtor dictate (what it is written), and he should be cautious of Allah his Lord, and he should not reduce any of his debt. If the debtor is a weak person or weak (the circumstances) or he himself is not able to dictate then let his guard to dictate honestly. And witness with two witnesses of the men among you. If there are no two men then (may) be a man and two women from the witnesses of your witnesses, so that if one forgets one another reminds him. Do not witness witnesses are reluctant when they are summoned and you are tired of writing the debt, both small and large, until the deadline for paying it. That is, fairer in the sight of God and more able to strengthen the testimony and closer to your no doubt, (write it your muamalah), unless it is a cash-trade that you run between you, then there is no sin for you, ) you did not write it. And witness if you buy and sell; and let not the writers and witnesses overwrite each other. if ye do (so) then surely it is a wickedness in you. And fear Allah; God taught you; and Allah knows all things ${ }^{25}$

\section{Benefits of Writing in Islam}

One of the names in the Qur'an is the Book. Even the mention of the rd bible is much more than the word of the Qur'an in the holy book of the Qur'an itself. The word of the Book is mentioned 230 times while the Qur'an is only 58 times.

Al-Qur'an means reading while Al-Kitab means writing. More use of the word Al-Kitab than the Qur'an shows the high recommendation of the Qur'an to write without conveying the importance of reading at the same time.

Here are 5 benefits of writing based on Al-Qur'an and As-Sunnah:

1. Quill

Quill is a pen made of chicken feathers, broad feathers with a hollowed hilt (calamus) that is pointed at the point and dipped into the ink for writing. Quill used since medieval times.

${ }^{25}$ http://ayatalquran.net/2015/01/surah-al-baqarah-the-cow-terjemah-bahasa-inggris, diaksesRabu 18 Juli 2018, pkl. 22.00 . 
2. Writing Brush

Writing Brush or paint brush from synthetic feather or natural feathers that way to write it by hand and immersed in ink. The brush has been used on Chinese calligraphy more than 4000 years ago.

3. Egyptian Reed Pen

Egyptian quills, small pointed feathers, to paint hieroglyphs on clays to write on lontar leaves with ink.

\section{Lead Pencil}

A pointing pencil is a longitudinal pencil with an ornate tip. First used in medieval times, then replaced with hard charcoal.

5. Roman Metal Pen

Roman steel pens are stationery made of metal. Discovered by the Romans in ancient times. This pen is embryonic to modern metals that became known in the 19th century.

6. Stylus, stylus, tool of lead tin

Used in ancient Greece to scratch candlesticks. The flat tip is used to remove etching (scratches).

\section{Steel Pen (Steel Pen)}

The tip of the line sphere on the handle, dipped into the ink tub for writing. In subsequent developments, various stationery innovations are made, for example pen foundation: ballpoint pen (ballpoint pen), marker (colored pointer, propelling pencil (mechanical pencil), pencil (pencil), even refill. 


\section{REFERENCES}

Axelrod, B. Rise \& R. Coopers, the St. Martin's Guide to Writing, New York: St Martin's Press, Inc, 1985.

Fakhrudin, Arif\&SitiIrhamah, Al Hidayah Al-Qur'an TafsirPer Kata Tajwid KodeAnga, Tangerang Selatan: KalimKaryaIlmuKaryaHayati, 2011. http://ayatalquran.net/2015/01/surah-al-baqarah-the-cow-terjemah-bahasainggris, diakses, Rabu, 18 Juli 2018, pkl. 2032

http://ayatalquran.net/2015/02/surah-al-Alaq-the-eathquake-terjemah-bahasa inggris, diakses, Kamis 19 Juli 2018, pkl. 15.20.

http://ayatalquran.net/2015/01/surah-al-mulk-the-prostration-terjemah-bahasainggris, diakses, Rabu 18 Juli 2018, pkl 11.10.

http://ayatalquran.net/2015/02/surah-al-Qalam-the-earhquake-terjemah-bahasainggris, diakses, Kamis 19 Juli 2018, pkl. 15.10.

http://ayatalquran.net/2015/01/surah-as-sajdah-the-prostration-terjemah-bahasainggris, diakses, Rabu, 18 Juli 2018, pkl 11.00.

http://ayatalquran.net/2015/02/surah-az-zalzalah-the-earthquake-terjemahbahasa-inggris, diakses, Kamis 19 Juli 2018, pkl.15.00.

Kasupardi, Endang\&Supriatna, PengembanganKeterampilanMenulis, Jakarta: Trans MandiriAbadi, 2010.

Linse. Caroline, T. Practical English Language Teaching: Young Learner, New York: McGraw-Hill, 2005.

.Moreillon, Judi, Collaborative strategies for teaching reading comprehension, Chicago: American Library Association, 2007

Newton, I.S.P. Nation, Jonathan, Teaching ESL/EFL Listening and Speaking, Francis: Routledge, 2009.

Ur, Penny, A Course in Language Teaching, New York: Cambridge University Press, 1991. 